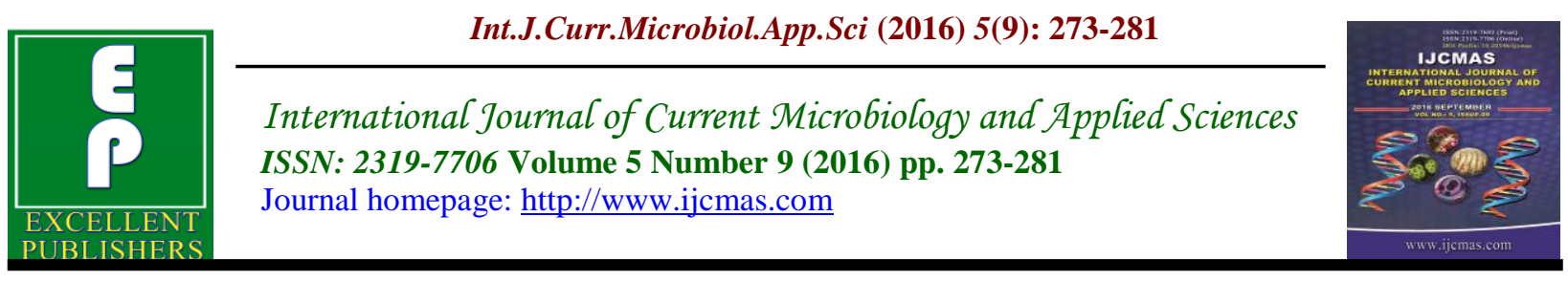

Review Article

http://dx.doi.org/10.20546/ijcmas.2016.509.031

\title{
Distribution and Diversity of Aquatic Insects in Himachal Pradesh, India: A Review
}

\author{
Aakriti Chauhan* and S.C. Verma \\ Department of Environmental Science, Dr YS Parmar University of Horticulture \\ and Forestry, Nauni, Solan-173230 HP \\ *Corresponding author
}

\begin{abstract}
A B S T R A C T
\section{Keywords}

Aquatic Insects, Faunal

Diversity,

Himachal Pradesh, India.

Article Info

Accepted:

13 August 2016

Available Online:

10 September 2016

Aquatic insects biodiversity is being increasingly imperilled by a range of factors globally. Freshwater aquatic insects inhabit river and stream beds, lakes and reservoirs and are associated with various types of substrates such as mineral sediments, detritus, macrophytes and filamentous algae. The distribution of aquatic organisms is the result of interactions among their ecological role, the physical conditions that characterize the habitat, and food availability. Biodiversity is not only the richness of species; it is also their genetic variety and the multiple habitats and ecosystems in which these plants and animals live. Ecosystems contain both the living plants and animals and the nonliving elements (water, sunlight, soils) on which they depend. At high altitudes, insects are the dominant animals. Insects successfully dominant almost every conceivable habitat and flourish at the highest limits of existence of animal life. The high altitude insects are an ecologically highly specialized group of mountain autochthonous species. Insects have the broad range of adaptation and can survive in the extreme environmental conditions, prevailing at high altitudes such as in Himachal Pradesh.
\end{abstract}

\section{Introduction}

\section{Faunal Diversity: Global and Indian Status}

Insects are the largest group among animals and plants in the world. It is commonly believed that insects makes 75-80 per cent of the total animal species on this planet (Ehrlich and Wilson, 1991). Hammond (1992) estimated about 9,50,000 species of insects, although lower figures of around 7,50,000 (May, 1998) are generally quoted. The insect fauna of India is vast. Lefroy and Howlett (1909) in the monumental book
'Indian Insect Life' reported 25,700 Indian species. Roonwal (1989) estimated that insects constitute two-thirds of the total fauna in India and comprise nearly 1, 00,000 species, of which about half remain yet to be studied. Varshney (1997) has reported 589 families and 51450 species of insects from India. Alfred et al. (1998) estimated 59353 species of insects from India belonging to 619 families. Indian insects belong to 27 orders of which Coleoptera is most dominant with about 15,500 species. Butterflies and Moths with about 15,000 
species is another important group. These are followed by Hymenoptera (10,000 spp.), Diptera (6093 spp.) and Hemiptera (6500 spp.) (Varshney, 1998).

\section{Fresh water and aquatic insects: Global status}

Inland water covers less than 1 per cent of the earth surface and harbour 10 per cent of all known animal species of which 60 per cent is composed of aquatic insects. This diversity today numbers close to 100000 described species (Balian et al., 2008). Aquatic insects spend one or more stages of their life cycles in the water with the majority living in water as eggs and larvae and moving in terrestrial habitats as adults. They play important ecological roles in both aquatic and terrestrial realms as primary consumers, detritivores, predators and pollinators. The fossil record suggests that all aquatic insects groups is the result of the invasion of freshwaters by terrestrial groups (Wootton, 1988). Although belonging to 12 orders aquatic insects may represent more than 50 separate invasions. Ephemeroptera, Odonata, Plecoptera, Trichoptera and Megaloptera are almost exclusively restricted to freshwater by an aquatic larval stage and make up over 27000 known species of which over half belong to Trichoptera the remaining diversity includes over 10 per cent of the Hemiptera sub order Heteroptera, approximately 30 per cent of Diptera, approximately 3 per cent of Coloeoptera and very small proportions of Hymenoptera, Lepidoptera, Neuroptera and Orthoptera. Freshwater habitat can be broadly grouped into running (lotic) and standing (lentic) water bodies and majority of aquatic species is restricted to one or the other. The relatively short geological life span of standing waters makes dispersal necessary for lentic species whereas running water habitats are more geologically stable and therefore lotic species may be less dispersive. The observations imply that freshwater species diverged and survived under very different impacts, timing and scales and at very different rates of turnover, depending on their habitat and thus dispersal capacity.

Fresh water are diverse which includes ponds, lakes, springs, rivers, wetlands, reservoirs and ditches (Wetzel, 2001).The transition to fresh water demanded adaptation in mechanisms of thermo and osmoregulation, respiration feeding and locomotion. Among the most notable characteristics of freshwaters are their daily and seasonal temperatures which are more stable than air and soil temperatures. Freshwater occupy low position on the landscape where they accumulate nutrients and detritus (Dijkstra et al., 2014).

\section{Habitat Stability}

There are about 45000 species of insects known to inhabit diverse freshwater ecosystems (Balaram, 2005). Less than 3 per cent of all species of insects have aquatic stages in some freshwater biotopes, insects may comprise over 95 per cent of the total individual or species of macro invertebrates. They play important ecological roles in keeping freshwater ecosystems functioning properly. According to Lewis and Gripenberg (2008) aquatic insects often make good indicators because they are present in some quantity in almost every type of habitat and many are habitat specialists. Aquatic insects are used for monitoring the health of aquatic environments because of their differential response to stimuli in their aquatic habitat and determining the quality of that habitat (Merritt et al., 2008). The presence or absence of certain families of aquatic insects can indicate whether a particular water body is healthy or polluted. 
Aquatic insects may considered model organisms in analysing the structure and function of the fresh water ecosystem because of their high abundance, high birth rate with short generation time, large biomass and rapid colonization of fresh water habitats. Aquatic insects are found associated with water for most part of their life cycle, any change in their number and composition in the population at a given time and space may indicate a change in the water quality. They also act as indicator of trophic structure, water quality and eutrophication of the aquatic ecosystems (Varma and Pratap, 2006). Aquatic insects are integral part of the aquatic ecosystem, they have both ecological and economical value. They have been the primary to for studying ecology, growth of population, evolution, genetics and many other areas of biology. Some of aquatic insects break down the dead leaves and other plant parts that fall into the water body from land. This material provides the base of food chain in aquatic environments.

Some scrape the algae that grow on all firm surfaces in water, such as rocks, logs leaves and stem of live rooted plants. This layer of algae, which produces much oxygen and food for other organisms, is more productive if this is kept thin by grazing of aquatic insects and other invertebrates. Some specific aquatic insects filter fine particles that are suspended in water. This is useful as it helps to keep the water clean enough for light to penetrate where algae and other plants are growing on the bottom. Other aquatic insects mix the soft bottom sediments as they burrow in search of food. This makes the bottom healthier for organisms because it puts oxygen from the water into the bottom (Choudhary and Ahi, 2015).

\section{Types of aquatic insects}

Aquatic insects include following taxonomic orders:

i. Collembola- the springtails (springs and spring ponds)

ii. Ephemeroptera- the mayflies (lakes and streams)

iii. Odonata-the dragonflies and damselflies (lakes and streams)

iv. Plecoptera-the stone flies(streams)

v. Hemiptera- the true bugs(lake and stream margin)

vi. Neuroptera/ megaloptera- the dobsonflies, alderflies and spongillaflies, parasitic on sponges (mainly streams)

vii. Trichoptera- the caddisflies(lakes and streams)

viii. Lepidoptera- the butterflies and moths (aquatic caterpillar)

ix. Coleoptera- the beetles(lakes and streams)

x. Hymenoptera- diving wasps (terrestrial, parasitic on aquatic insects)

xi. Diptera- the true flies (all aquatic habitats).

\section{Biodiversity of aquatic insects}

Aquatic biodiversity is one of the most essential characteristics of aquatic ecosystem for maintaining its stability (Vinson and Hawkins, 1998). Aquatic ecosystems are under increasing pressure from various kinds of disturbances (Tachet et al, 2003). This situation threatens both aquatic living resources and human population (Ramade, 2002). Biodiversity loss in freshwater ecosystem is an increasing phenomenon, mainly due to human activities (Abell, 2002). The main causes are the habitat destruction and defragmentation, exotic species introduction and global 
climate change impacts (Saunders et al., 2002). Removal or loss of aquatic insects can cause negative effects in the ecosystems stability and diversity (Krishnan et al., 1988). Certain nutrients are known to travel from agricultural and urban lands into rivers by means of runoff (Hynes, 1970; Smart et al., 1981) and influence the distribution and abundance of macro invertebrates depending on their tolerance and habitat requirements (Townsend et al., 1997). Water quality of the natural water bodies not only helps to ascertain the pollution control measures but also indicates its impact on aquatic ecosystem. Benthic macro invertebrates are good indicators of watershed health and fluctuations in aquatic insect communities give quick information on water quality (Singh, 1997). The Knowledge regarding distribution of benthic macro invertebrate fauna in river ecosystem of Himachal Pradesh is limited and highly fragmentary.

\section{Biodiversity of Aquatic insects in Himachal Pradesh}

The aquatic insects contributed 99.14 per cent to the macro-invertebrate population in Sheerkhad stream in Bilaspur district of Himachal Pradesh during 1983-85 were represented by Ephemeroptera (40.67\%), Trichoptera (33.65\%), Plecoptera $(10.11 \%)$, Coleoptera (7.77\%), Diptera (5.03\%), Odonata $(1.01 \%)$ and Hemiptera $(1.00 \%)$ in the order of their abundance (Joshi,1991). The highest densities of benthic animals were recorded during summer months with maximum population of Ephemeroptera (149 no. $/ \mathrm{m}^{2}$ in May,1984) and further reported that winter crop of the macroinvertebrates was found to be dominated by the larvae of caddis flies $\left(96\right.$ no. $\left./ \mathrm{m}^{2}\right)$ was recorded in February, 1985. The maximum occurrence of the nymphs of stone flies was also recorded during winter months. The average density of fly larvae and aquatic beetles in Sheerk had were 5 and 8 no. $/ \mathrm{m}^{2}$, respectively.

Himalaya which is the source of all the north Indian rivers is the most ideal region for the study of aquatic insects life. In recent years some attempts have been made to study the Ephemerida, Plecoptera and Diptera of in the upper catchment of river Beas (Khan and Sahni, 1978; Kulshrestha, 1978). Mani and Singh (1955), and Mani (1962) have recorded the phenomenon of mass assemblage of insects, particularly Coccinellidae, on the high mountain slopes, ridges and snow fields.

Lahiri et al., (2007) recorded Gynacantha pallampurica sp. Nov. of odonata from Palampur area of Himachal Pradesh. Sharma et al., (2006) studied macro invertebrates in Behta river of Paonta Sahib in Himachal Pradesh. They reported 30 genera belonging to 10 families of taxonomical group like Ephemeroptera, Trichoptera, Plecoptera, Coleoptera, Heteroptera, Odonata, Diptera Mollusca, Oligochaetes etc. in different composition inhabiting the river. Sharma and Dhanze (2012) evaluated macrobenthic fauna in hill streams of Kangra district of Himachal Pradesh and reported that Dehar Stream recorded Ephemeroptera as dominating group and showed its existence throughout the year and it varied from 28.8 to $88 \%$ of total benthos at various sites of this stream. Diptera was the next dominating group which varied from 13 to $52 \%$ of total benthos. Popualtion of Trichoptera, was high (6.5 to $29 \%$ of total benthic fauna) during winter. The Coleoptera were noticed during the winter season and constituted 0.76 to $24.74 \%$ of total benthic fauna. The Odonata were reported only during rainy season. Similarly in Gaj Stream, Ephemeroptera was the dominating group and varied from 32 to $80 \%$ of total benthos during summer season. 
The Diptera were the next dominating group and varied between 12 to $60 \%$ of total benthos. TheTrichoptera, a co-dominating group were reported mainly during winter season and the population varied between 2 to $14.49 \%$ of total benthos. Coleoptera was also noticed during winter months. In case of Banner Stream, the percentage of Ephemeroptera in total benthic population varied from 14.74 to $72.57 \%$ of total benthic population. Diptera population varied from 7.98 to $78.85 \%$ of total population of benthos at different sites. The Trichoptera, a co-dominating group, were reported almost in all the seasons. Coleoptera were reported only from Haripur, Saddar and Manjhi in different seasons. The Odonata varied from 0.16 to $40 \%$ of total benthos. In Neugal stream, the percentage population of Ephemeroptera varied between 7.12 to $82 \%$ of total benthic fauna at various sites. The percentage of Diptera varied between 8 and $90 \%$ and a winter peak was observed almost at all the sites. Trichoptera were mainly noticed during the winter and constituted 1.13 to $41 \%$ of the total benthic population.

Though Coleoptera were found during winter months at all the sites, at Punner their presence was noticed during summer also. The percentage of population was much less at Parour (0.01 to $0.35 \%)$ but higher at Punner $(0.55$ to $3.7 \%)$. Incase of Binwa Stream, a winter peak of Ephemeroptera was noticed and its $\mathrm{s}$ population varied between 15 to $80.85 \%$ of total benthos. The next dominating group was Diptera which varied between 12 to $53.5 \%$ at different sampling sites. The Coleoptera, a co-dominating group, which constituted 0.74 to $15.6 \%$ of total benthic fauna. Trichoptera which were mainly observed during summer and winter months from all the sites and constituted 8.6 to $29.82 \%$ of total benthic fauna. Plecoptera constituted $1.06 \%$ of total benthic fauna.

Singh and Baniyal (2013) recorded 10 species belonging to 8 genera spread over 5 families of Odanata in Khajjiar Lake of Chamba district of Himachal Pradesh. Family Libullidae supported the highest number of species (6 species, under 4 genera) and all other families have been represented by a single species each. Out of these ten, eight belongs to Anisoptera (dragonflies) and two to Zygoptera (damselflies). Ghosh and Hedge (2013) recorded 13 species belonging to 10 genera and 3 families (Gyrinidae, Dytiscidae and Hydrophilidae) of aquatic Coleoptera from different parts of Renuka wild life Sanctuary of Himachal Pradesh. The species Rhantaticus congestus (Klug) and Hydaticus ricinus Wewalka was the first time recorded from Himachal Pradesh state and 9 species among 13 species are first recorded from Renuka Wildlife Sanctuary. The aquatic beetles recorded were Dineutus (Protodineutus) indicus Aube, 1938 under Gyrinidae, Rhantaticus congestus (Klug, 1833), Hydaticus (Prodaticus) ricinus Wewalka,1979, Hydroglyphus flammulatus (Sharp,1882), H. pradhani (Vazirani,1969), L. inefficiens (Walker,1859), L. sharpi Regimbart, 1889 under Dytiscidae and Sternolophu srufipes (Fabricius, 1792), Amphiop spedestris Sharp, 1890, Helochare sanchoralis Sharp, 1890, B. pulchellus Mcleay, 1825, Regimbartia attenuata Fabricius, 1801 under Hydrophilidae. Biswas (2000) recorded 20 aquatic beetles' species under 6 families from Renuka Wildlife Sanctuary. Biswas (2000) treated Hydaticus fabricii Macleay as a synonym for Hydaticus ricinus Wewalka; altogether, a list of 28 aquatic species belonging 6 families (Gyrinidae, Dytiscidae, Hydrophilidae, Georyssidae, Byrrhidae and 
Elmidae) of aquatic Coleoptera currently known from Renuka Wildlife Sanctuary.

Gupta et al., (2014) recorded 118 individuals $/ \mathrm{m}^{2}$ of aquatic insects under 6 families and 5 orders under different land uses and seasons in Parwanoo area of Solan district of Himachal Pradesh. Out of which 39 individuals $\mathrm{m}^{-2}$ of aquatic insects was under agriculture land use. Maximum number $\left(6\right.$ individuals $/ \mathrm{m}^{2}$ each Batidae: Ephemeroptera and Hydropsychidae: Trichoptera) of aquatic insects were found during winter season, followed by Cordullidae (4 individuals) of Odonata and Leuctridae ( 3 individuals $/ \mathrm{m}^{2}$ ) of Plecoptera while during rainy and winter season only one individual of family Gerridae of Hemiptera was observed. Maximum number (48 individuals $/ \mathrm{m}^{2}$ ) of aquatic insects were recorded under forest land use. Highest number ( 8 individuals $/ \mathrm{m}^{2}$ ) of aquatic insects of Hydropsychidae family of Trichoptera followed by Baetidae of Ephemeroptera, Leuctridae of Plecoptera (both 6 individuals/ $\mathrm{m}^{2}$ ), Cordullidae (4 individuals/ $\mathrm{m}^{2}$ ) of Odanata and Gerridae and Notonectidae of Hemiptera (both 1 individuals/ $\mathrm{m}^{2}$ ) were recorded during winter season. The lowest number (31 individuals/ $\mathrm{m}^{2}$ ) of aquatic insects were recorded under urban land use. Maximum number (4 individuals) of aquatic insects of Hydropsychidae of Trichoptera and Batidae (4 individuals/ $\left.\mathrm{m}^{2}\right)$ of Ephemeroptera followed by Leuctridae (3 individuals/ $\mathrm{m}^{2}$ ) of Plecoptera, Cordullidae (3 individuals $/ \mathrm{m}^{2}$ ) of Odanata, Gerridae and Notonectidae (both 1 individual $/ \mathrm{m}^{2}$ ) of Hemiptera were recorded under urban land use during winter season. During winter season 62 individuals $/ \mathrm{m}^{2}$ of aquatic insects were recorded followed by summer season (34 individuals/ $\mathrm{m}^{2}$ ) and rainy season $(22$ individuals $/ \mathrm{m}^{2}$ ). Simpson's Diversity Index $(0.90)$ indicated high diversity of aquatic insects.
Chauhan et al., (2015) assessed aquatic insects fauna in mountaineous streams under different land uses and seasons in Kandaghat block situated in Solan district of Himachal Pradesh under different land uses (agriculture, forest and urban) and seasons (rainy, winter and summer) and found that there was variation in distribution and abundance of aquatic insect fauna as well as biotic indices. A total of 80 individuals $\mathrm{m}-2$ and 59 individuals $\mathrm{m}-2$ of aquatic insects was recorded under agriculture and urban land uses, respectively. Among all the land uses, forest land use recorded highest aquatic insects $(107 \mathrm{~m}-2)$. Maximum aquatic insects $(123 \mathrm{~m}-2)$ were during summer season with Simpson's biodiversity index of 0.01 , whereas agriculture land use $(0.11)$ was highest under different land uses. Maximum diversity of insects indicated less disturbance of the streams. EPT (Ephemeroptera, Plecoptera and Coleoptera) index for agriculture, urban and forest land uses was 3.46, 3.70 and 3.56, respectively. Percentage of individuals of Trichoptera in water bodies under agriculture, Urban and Forest land use were 12.60, 10.98 and $10.16 \%$, respectively. Hemiptera were maximum $(7.31 \%)$ under forest land use and minimum in Urban land use $(2.03 \%)$, whereas order Odonata were maximum under Forest land use $(9.31 \%)$ followed by urban $(5.69 \%)$ and agriculture land use (4.47\%).

Sharma et al., (2015) highest number of individuals of aquatic insects $/ \mathrm{m} 2$ from forest land use (164) followed by agriculture (153) and urban (144), Maximum numbers were collected during summer seasons. Trichoptera was more diverse with maximum number of individuals $/ \mathrm{m} 2$ whereas Plecoptera recorded minimum number of individuals, irrespective of seasons and land use. Highest EPT index was recorded under forest land use of the 
area followed by agriculture and urban whereas EPT biotic index and family biotic index was highest under urban land use followed by agriculture.

\section{References}

Abell, R. 2002. Conservation biology for biodiversity crisis : Fresh water follow up. Conser. Biol., 16: 1435-1437.

Alfred, J.R.B., Das, A.K., Sanyal, A.K. 1998. Faunal diversity in India, Zoological Survey of India, Kolkata, pp. 495.

Aube, C. 1838. Hydrocanthares et gyriniens. In: DEJEAN P.F.M.A. (ed.): Species general des coleopteres de la collection de M. le Comte Dejean. Vol. 6. Paris, Mequignon Pere et Fils, xvi +804 pp.

Balaram, P. 2005. Insect of tropical streams, Curr. Sci., 89: 914.

Balian, E.V., Leveque, C., Segers, H., Martens, K. eds. 2008. Freswater Animal Divesity Assessment. Developments in Hydrobiology198. Dordrecht, The Netherlands: Springer.

Biswas, S. 2000: Aquatic Coleoptera, Wetland Ecosystem Series 2: Fauna of Renuka Wetland, Zoological Survey of India, 97-103.

Chauhan, A., Verma, S.C., Thakur M. 2015. Bioassessment of water quality of mountainous streams under different land use in Solan district of Himachal Pradesh, India. Int. J. Bio-reso. and Stress Manage., 6(1): 161-166.

Choudhary, A., Ahi, J. 2015. Biodiversity of fresh water insects: A review. The Int. J. Engi. Sci., 4(10): 25-31.

Dijkstra, K.B., Monaghan, M.T., Pauls, S.U. 2014. Freshwater Biodiversity and Insect Diversification. Annu. Rev. Entomol., 59: 143-163.

Ehrlich, P.R., Wilson, E.O. 1991. Biodiversity studies: Science and policy. Sci., 253: 758-762.

Fabricius, J.C. 1792. Entomologia systematica emendata et aueta. Vol. I: 1. - Hafniae, $X X+330 \mathrm{pp}$

Ghosh, S.K., Hegde, V.D. 2013. On a collection of aquatic beetles (Order: Coleoptera: Gyrinidae, Dytiscidae and Hydrophilidae) of Renuka wildlife sanctuary, Himachal Pradesh, India Rec. Zoological Survey of India, 113(Part-2): 61-67.

Gupta, K., Verma, S.C., Thakur, M., Chauhan, A. 2014. Impact of land uses on surface water quality and associated aquatic insects at Parwanoo area of Solan Dostrict of Himachal Pradesh, India. Int. J. Bio-reso. and Stress Manage., 5(3): 427-431.

Hammond, P.M. 1992. Species inventory. In: Global biodiversity: Status of the earth's living resources, Chapman and Hall, pp. 17-39.

Hynes, H.B.N. 1970. The ecology of running waters. Liverpool University Press, Liverpool. 555P.

Joshi, C.B. 1991. Benthos composition of a hill stream in Western Himalayas. $J$. Ind. Inst. Sci., 71: 373-382.

Khan, R.A., Sahni, N.K. 1978. Preliminary report on a Survey of Aquatic Ecosystem of the River Beas with special reference to insects., Mem. Sch. Ent., 6: 107-114.

Klug, J.C.F. 1833. Bericht uber eine auf Madagascar veranstaltete Sammlung von Inscetcn aus der Ordnung Coleoptcra. - Berlin.

Krishnan, K., Marshall W D., Hatch, W I. 1988. Ionic Alkylleads in Salt Marsh Periwinkles (Littorina irrorata). Environ. Sci. Technol., 22 : 806.

Kulshrestha, A.K. 1978. Chironomidae (Diptera) of River Beas Ecosystem. Mem. Sch. Ent., 6: 113-114.

Lahiri, A.R., Sandhu, S., Walia, G.K. 2007. Gynacantha pallampurica sp. Nov. 
from northern Himachal Pradesh, India (Odonata: Aeshnidae) Rec. zoological Survey of India: 107(3) : 45-49.

Lefroy, H.M., Howlett, F.M. 1909. Indian Insect Life, Thacker, Spink and Co., Calcutta, pp. 786.

Lewis, O.T., Gripenberg, S. 2008. Insect seed predators and environmental change. J. Appl. Ecol., 45(6): 15931599.

Maclhay, W.S. 1825. Annulosa Javanica. Vol. I. - London, XII + 150 pp.

Mani, M.S. 1962. Introduction to High Altitude Entomology. London, Methuen and Co, 305 pp.

Mani, M.S., Singh Santokh. 1955. Entomological survey of the Himalaya. Part XIII. Second Entomological Expedition to the North-West (Punjab) Himalaya., Agra Univ. J. Res. Sci., 4(Suppl.): 717-740.

May, R.M. 1988. How many species are there on earth? Sci., 241: 1441-1449.

Merrit, R.W., Cummins, K.W., Berg, M.B. 2008. An introduction to the aquatic insect of Rhgimhart, M. 1889. Contributions a la faunc indo-chinoisc. 2c memoire. Hydrocantharcs. - Annls Soc. ent. Fr., (6)9: 147-156.

Ramade, F. 2002. Dictionnaire encyclopedique de I, ecologieet des science de I, environment. Encyclopedic dictionary of ecology and environment sciences. $2^{\text {nd }}$ edition, Dunot, Paris.

Roonwal, M.L. 1989. The importance of insect taxonomy in India. Hexapoda., 1: $1-2$.

Saunders, D.L., Meeuwing, J.J., Vincent, A.C.J. 2002. Fresh water protected areas: strategies for conservation, Conser. Biol., 16: 30-41.

Sharma, I., Dhanze, R. 2012. Evaluation of macrobenthic fauna in hill stream environment of Western Himalaya,
India. J. Threatened Taxa, 4(9): 28752882.

Sharma, M.P., Sharma, S., Goel, V., Sharma, P., Kumar, A. 2006. Water quality assessment of Bheta river using benthic macro invertebrates. Life Sci. J., 3(4): 68-74.

Sharma, P., Verma, S.C., Thakur, M., Bhardwaj, S.K., Kaushal, R.K. 2015. Impact of different land uses on surface water quality in mid hills of Himachal Pradesh, 136p. Paper presented in National Symposium on Modern Agro-Technologies for Nutritional Security and Health during 21-23 April, 2015 at Dr YS Parmar University of Horticulture and Forestry, Nauni, Solan, H P.

Sharp, D. 1882. On aquatic carnivorous Coleoptera or Dytiscidae. The Scientific Transactions of the Royal Dublin Society., (2) 2: 179n1003 + pls. $7 \mathrm{n} 18$.

Sharp, D. 1890: On some aquatic Coleoptera from Ceylon. - Trans, Ent. Soc. Lond. 1890: 339-359.

Singh, S.K. 1997. Studies on hydrobiological relationship of aquatic insects found in water water body of Muzaffarpur (Bihar) Ph.D Thesis, B U Muzaffarpur (Bihar).

Singh, V., Banyal, H.S. 2013. Odonate fauna of Khajjiar lake (Mini Switzerland) of Chamba district of Himachal Pradesh. The Bioscan, 8(1): 281-287.

Smart, M.M., Barney, T.W., Jones, J.R. 1981.Watershed impact on stream water quality: A technique for regional assessment. J Soil and water Conser., 63: 297-300.

Tachet, H. Richoux, P., Bourneau, M., Usseliopolatera, P. 2003. Invertebratesd eaudouce, systematique, biologie, ecologie. Fresh water Invertebrates: Systematic, 
Biology, Ecology, CNRS edition, Paris.

Townsend, C.R., Scarsbrook, M.R., Doledec, S. 1997. The intermediate disturbance hypothesis, refugia and biodiversity in streams. Limnol. Oceanograp., 42:938-949.

Varma, M.C., Pratap, R. 2006. Haematol. Ecotoxicol., 1(1): 13-20.

Varshney, R.K. 1997. Index Rhopalocera Indica. Part III. Genera of butterflies from India and neighbouring countries (Lepidoptera: C) Lycaenidae, 31: 83138.

Varshney, R.K. 1998. Insecta. In: Faunal diversity in India, Zoological Survey of India, Kolkata, pp 145-157.

Vazirani, T.G. 1969. Contribution to the study of Aquatic Beetles (Coleoptera) 2. A Review of the Subfamilies Noterinae, Laccophilinae, Dytiscinae and Hydroporinae (in part) from India, Oriental Insects., 2(3-4): 211-341.

Vinson and Hawkins.1998. Biodiversity of stream insects. Variations at local, basin and regional scales. Annu. Rev. Entomol., 43: 271-293.
Voshell, J.R. 2002. A guide to common freshwater invertebrates of North America. Mc Donald and Woodward Publishing Company, Blacksburg. Virginia: 442 .

Walker, F. 1859. Characters of some apparently undescribed Ceylon insects. - Ann. Mag. nat. Hist. (3) 2:202-213. Wiener Coleopterologenverein, Zool.-Bot. Ges. Osterreich, Austria; download under www.biologiezentrum.at in M.A. JACII \& L. Jl (eds.): Water /hellesof Chimt. Vol. I. 1995

Wetzel, R.G. 2001. Limnology. San Diego, CA: Academic, $3^{\text {rd }}$ ed.

Wewalka, G. 1979. Revision der Artengruppe des Hydaticus (Guignotites) fabricii (Macleay), (Col., Dytiscidae). Koleopterologische Rundschau., 54: 119-139.

Wootton, R.J. 1988. The historical ecology of aquatic insects: an overview. Palaeogeogr, Palaeoclimentol. Palaeoecol., 62: 477-92.

\section{How to cite this article:}

Aakriti Chauhan and S.C. Verma. 2016. Distribution and Diversity of Aquatic Insects in Himachal Pradesh, India: A Review. Int.J.Curr.Microbiol.App.Sci. 5(9): 273-281. doi: http://dx.doi.org/10.20546/ijcmas.2016.509.031 